\title{
JURY REPORT ON THE KVS AWARD FOR THE BEST DOCTORAL THESIS IN ECONOMICS OF THE ACADEMIC YEARS 2006-2007 \\ AND 2007-2008
}

BY

\begin{abstract}
ERIC VAN DAMME*, MARTIN FASE**, PHILIP HANS FRANSES***, JOB SWANK ${ }^{* * *}$, JULES THEEUWES****
\end{abstract}

The KVS Award for the best doctoral thesis was instituted in 1999 by the Royal Netherlands Economic Association on the occasion of its 150th anniversary. Its aim is to promote the study of economics. The KVS medal is awarded every 2 years to the PhD student who wrote the best doctoral thesis in economics. The award consists of a medal and a prize of EUR 5.000. The first prize-winner in 2000 was Vincent Buskens for his thesis on Social networks and trust, the second in 2002 was Sander Onderstal for his Papers in auction theory. In 2004 Stefan Wuyts won the award for his thesis on Partner selection in business markets and in 2006 the prize went to Robert Sparrow for his thesis on Health, education and economic crisis: protecting the poor in Indonesia.

This time the long list of 11 theses submitted by the Dutch economic faculties as their top theses defended in the past 2 years consists of (in alphabetical order):

Maarten Bosker, The empirical relevance of geographical economics;

Lammertjan Dam, Corporate social responsibility and financial markets;

Roy Hoevenaars, Strategic asset allocation and asset liability management;

Ralph Koijen, Essays on asset pricing;

Sandra Maximiano, Essays in organizational economics;

Valeri Nikolaev, Financial reporting, debt contracting and valuation;

Ana Llena-Nozal, On the dynamics of health, work and socio-economic status;

Remco Prins, Modeling consumer adoption and usage of value-added mobile services;

\footnotetext{
* CentER, University of Tilburg, P.O. Box 90153, 5000 LE,

Tilburg, The Netherlands; e-mail: Eric.vanDamme@uvt.nl

** Wagenmakerslaan 30, 2012 DJ, Haarlem,

The Netherlands; e-mail: mmg.fase@planet.nl

*** Faculteit der Economische Wetenschappen, Erasmus Universiteit Rotterdam,

P.O. Box 1738, 3000 DR, Rotterdam,

The Netherlands; e-mails: franses@few.eur.nl; jswank@few.eur.nl

**** Corresponding author: SEO Economic Research, University of Amsterdam,

Roetersstraat 29, 1018 WB, Amsterdam,

The Netherlands; e-mail: J.J.M.Theeuwes@seo.nl
} 
David Schrager, Essays on asset liability modelling;

Philippe Versijp, Advances in the use of stochastic dominance in asset pricing;

Rifka Weehuizen, Mental capital. The economic significance of mental health;

As can be seen the list covers a broad area of business and financial economics, general economics and econometrics. There are more manuscripts originating in the area of business economics than general economics. The large number of theses in the field of financial economics is notable and the presence of a thesis in the field of accounting is probably a first and is very much welcomed.

These are all excellent research manuscripts and the jury with professors Eric van Damme, Martin Fase, Philip Hans Franses, Job Swank and Jules Theeuwes (chair) had a difficult task to pick the winner. There are three relevant criteria for the selection of the winner: coherence, consistency and structure of content, scientific contribution and relevance for society. After much deliberation on the basis of these criteria the jury narrowed the choice set down to a short list of three theses. In the end one of them became the winner, but the other two are also of outstanding quality and deserve a special honorary mention in this jury report.

The first thesis that the jury wants to mention specifically is written by Ana Llena-Nozal on the Dynamics of health, work and socio-economic status. The jury praises the care and econometric professionalism that underlies the empirical analysis in the chapters. Two chapters aim at explaining health at young age as related to the socio-economic characteristics of the parents ingeniously using a regression discontinuity design. Two other chapters concentrate on the relationship between health and individual characteristics in the case of labour market participants and decompose the intricate relationship between health and work. This is a very well executed dissertation on a topic that is very relevant for society.

The second thesis that the jury wants to give a honorary mention is written by Sandra Maximiano and is called Essays on organizational econom$i c s$. The topic of organizational economics is a fast growing relatively new field in economics. The main topic of the thesis is the gift exchange between employer and employee. This innovative topic is expanded theoretically and empirically in a combination of chapters which exploit techniques and results from experimental economics and chapters using real life data and state-ofthe-art micro-econometrics.

In the final end, the jury decided unanimously to award the prize for the best thesis and the KVS medal to Ralph Koijen for his Essays on asset pricing. The chapters in his thesis, some of them already published in prestigious international journals (such as the Journal of Finance), are executed with superb economic skill. The theoretical developments are new and 
creative and sometimes critical of received theory. The data analysis and econometric analysis are pushing back the frontier of empirical finance. The chapter topics are very relevant for the present economic situation.

Characteristic of Koijen's thesis is his structural approach. Koijen takes theoretical models seriously and directly confronts their implications with data. He applies his approach to a wide variety of subjects such as mortgage timing, life cycle models, decentralized investment management, predictability of returns, and managerial ability. Koijen masters all these topics and makes fundamental contributions to each of them. For example, one of the most discussed questions in the finance literature is whether future returns on stocks can be predicted. Conventional wisdom states that the price-dividend ratio has no predictive power for future dividend growth rates and has only weak predictive power for future returns. By imposing the economic restrictions that follow from a structural present value model, Koijen, shows that the aggregate price-dividend ratio has strong predictive power. Another example can be found in the chapter on the ability of mutual fund managers. The consensus view is that only a small fraction of managers can recuperate fees and expenses. With the usual techniques it is hard to reliably estimate the effect of individual ability. By using a structural approach, Koijen is able to disentangle the two drivers of fund returns - ability and risk attitude of the manager - allowing him to obtain sharp estimates of ability.

It is with great pleasure that the jury awards the $2008 \mathrm{KVS}$ medal for best doctoral thesis to Ralph Koijen. We wish him all the best in his future career.

Open Access This article is distributed under the terms of the Creative Commons Attribution Noncommercial License which permits any noncommercial use, distribution, and reproduction in any medium, provided the original author(s) and source are credited. 